\title{
Features of the endocrine system of female adolescents in cotton-growing regions
}

\section{Bapayeva Gauri ${ }^{1}$, Kulbayeva Saltanat ${ }^{2}$, ZhumadilovaAkmaral. $^{2}$}

1 Department of obstetrics and gynecology, National research center for maternal and child health of the corporate fund «UMC», Astana, Kazakhstan

${ }^{2}$ South Kazakhstan State Pharmaceutical Academy, Shymkent, Kazakhstan

${ }^{3}$ Akhmet Yassawi International Kazakh-Turkish University

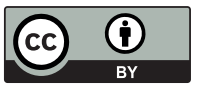

This work is licensed under a

Creative Commons Attribution $\mathbf{4 . 0}$

International License

J Clin Med Kaz 2017; 3(45 Suppl 3):29-34

Автор для корреспонденции: Бапаева Г.Б., Национальный научный центр материнства и детства Корпоративного фонда «UniversityMedicalCenter». Адрес: ул.Туран 32, Астана, Казахстан.

Тел: 8-7172-70-44-72,

E-mail: gauri.bapayeva@gmail.com

\section{Abstract}

Objective: to study the features of the endocrine system during the puberty in females living in regions, where organochlorine pesticides are widely used.

Materials and Methods:172 females (adolescents aged 10-17) were examined. They were divided into 2 groups, depending on their place of residence. The first (main) group included 89 females who from birth lived in a territory where organochlorine pesticides were widely used to grow cotton. The second (control) group included 83 females that did not live in such areas. Gonadotropic hormones - follicle stimulating (FSH), luteinizing (LH), prolactin (PL) - and steroid hormones - estradiol (E2), cortisol (K), dehydroepiandrosterone (DHEA) - were examined in all girls.

Results:It was found that the levels of FSH and LH in the females of the main group were significantly lower $(\mathrm{p}>0.02)$ during the whole period of puberty compared to their peers. Thus, the level of FSH at the age of $15-17$ years was in the main group $-10.79 \pm 0.98 \mathrm{mU} / 1$ compared to $16.26 \pm 0.21 \mathrm{mU} / 1$, and the level of $\mathrm{LH}-10.95 \pm 0.66 \mathrm{mU} / \mathrm{L}$ and $18.42 \pm 1.28 \mathrm{mU} / 1$, respectively. A similar pattern has been established with respect to prolactin at the age of 1012 years and $13-14$ years.

Conclusion: the females of the main group have a decreased production of gonadotropic and steroid hormones in the period of the formation of the reproductive system,.

Keywords: organochlorine pesticides, endocrine status, reproductivehealth.

ТҰЖЫРЫМДАМА

\section{МАҚТА ЕГЕТІН АУДАНДАРДА ТҰРАТЫН ЖАСӨСПІРІМ ҚЫЗДАРДЫН ЭНДОКРИНДІ ЖУЙЕСІНІН} ЕРЕКШЕЛІКТЕРІ

Бапаева Г.Б'

${ }^{1}$ Акушерлік және гинекология бөлімі, «UMC» корпоративтік қорының Ана мен бала ұлттық ғылыми орталығы, Астана, Қазақстан

${ }^{2}$ Оңтүстік-қазақстан мемлекеттік фарацевтика академиясы, Шымкент, Қазақстан

${ }^{3}$ Қ. А. Ясауи атындағы Халықаралық қазақ-түрік университет

Зерттеудің мақсаты: хлорорганикалық пестицидтер кеңінен қолданылған аймақта тұратын жасөспірім қыздардың эндокринді жағдайының ерекшеліктерін зерттеу.

Әдістері: 10-17 жас аралығындағы 172 жасөспірім қыздарға (89 негізгі топтағы және 83 - салыстырмалы) зерттеу жүргізілді. Тұрғылықты жеріне байланысты олар 2 топқа бөлінді. Бірінші (негізгі) топқа, мақтаны өсіруде хлорорганикалық пестицидтерді кеңінен қолданған аумақта тұратын 89 қыздар кірді.Екінші топқа (салыстырмалы) ауыл шаруашылығында мал шаруашылығымен айналысатын аумақта тұратын 83 қыз кірді. Ол қыздарда гонадотропты (ФСГ, ЛГ, ПЛ) және стероидты гормондарға (Е2, кортизол, ДГЭАСанықтау жүргізілді.

Нәтижесі: Жыныстық жетілу кезеңі бойынша негізгі топтағы қыздарда ФСГ және ЛГ деңгейлері құрыбыларымен салыстырғанда

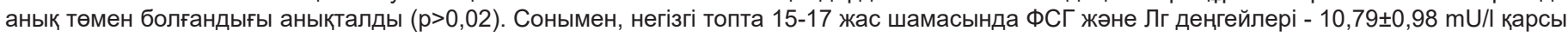

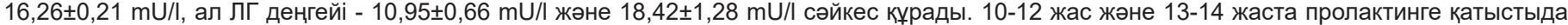
осыған ұқсас заңдылық тұрақталды.

Қорытынды: Негізгі топтағы қыздарда репродуктивті жүйенің қалыптасуы кезеңінде гонадотропты және стероидты гормондар өндірілуінің төмендеуі орын алып отыр.

Маңызды сөздер:хлорорганикалық пестицидтер, гормоналды жағдай, репродуктивті денсаулық. 
Бапаева Г.Б

'Отдел акушерства и гинекологии, Национальный научный центр материнства и детства корпоративного фонда «UMC», г. Астана, Казахстан

${ }^{2}$ Южно-казахстанская государственная фармацевтическая академия, г. Шымкент, Казахстан

${ }^{3}$ Казахско-Турецкий Университет им. Х.А. Ясави

дов

Цель: изучить особенности эндокринного статуса девочек - подростков проживающие в зоне воздействия хлорорганических пестици-

Материалы и методы: проведено обследование 172 девочек - подростков в возрасте 10-17 лет. В зависимости от места проживания они были разделены на 2 группы. В первую (основную) группу вошли 89девочки, которые родилисьи проживали на территории, где широко применялись хлорорганические пестициды при выращивании хлопка. Во вторую (сравнительную) группу вошла 83 девочек, которые родились и проживали на территории, где ведущей отраслью сельского хозяйства является животноводство.Всемдевочкам определялигормоны крови в плазме крови - ФСГ, ЛГ, ПЛ, эстрадиол, кортизол, ДГЭАС).

Результаты: Установлено, что уровни ФСГ и ЛГ у девочек основной группы были достоверно ниже (р>0,02) на протяжении периода

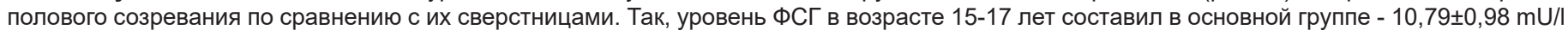

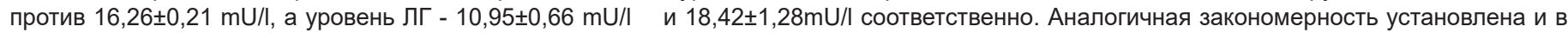
отношении пролактина в возрасте 10-12 лет и 13-14 лет.

Выводы в периоде становления репродуктивной системы у девочек основной группы имеет место пониженная продукция гонадотропных и стероидных гормонов.

Ключевые слова:хлорорганические пестициды, гормональный статус, репродуктивное здоровье.

\section{Kipicne}

Пестицидтер өзінің әсер етуі жағынан қауіпті химикаттар болып табыла отырып қоршаған ортада кең көлемде тарап отыр, олардың токсикалық әсерінің түрі шектелген таңдауда.

Қазақстан Республикасы мақта егуде соңғы он жылдықта қайта өркендеп келе жатқан ауыл шаруашылығы және текстильдік мата өндірісінің маңызды саласы болып табылады. Еліміздің оңтүстігінде бағытталған осы саладағы жұмыс жасайтындардың едәуір бөлігін әйел тұрғындары құрайды. Көптеген жылдар бойына мақта өндірісінде хлорорганикалық пестицидтер кеңінен қолданылған.

Пестицидтердің адам денсаулығына, ең алдымен репродуктивті жүйеге әсерін зерттеу мәселесі өзекті болып қала бермек, өйткені соңғы он жылда пестицидтерді қолдану 4 есе жоғарыдан асып отыр [1].

Бүгінгі таңда өте аз концентрациясында токсикалық заттар болып табылатын пестицидтер тұрақты органикалық ластаушылар тобына кіреді. Өзінің жасушалар кеңісітігінде орын алу қасиетімен адам ағзасына анағұрлым қауіп туғызатын, иммунды және репродуктивті жүйелер ауруларын, балаларда тума ақаулар, онкологиялық аурулармен жүретін көптеген патологиялық жағдайлармен үдерістердің себептері болып табылады [2-7]. ТОЛ зияндылығы дамып жатқан ұрпаққа плацента арқылы, ал нәрестеге емшек сүті арқылы өтеді [8-9].

Көптеген гомонтәрізді ксенобиотиктер (ГТК) эстрогенді және антиандрогенді әсері бар екендігін атап өту қажет.

R. Sharpe и N. Skakkeback [10] пікірлері бойынша осы заманғы адам «эстрогендердің виртуалді теңізінде өмір сүруде». Сондықтан, қоршаған ортада эстрогенді және антиандрогенді әсер ету қасиеті бар ГТК «жүгінің» көбеюі ерлер ағзасынадада көрінісін тапты. Қазіргі ерлердің репродуктивті жүйесінің «жүдеу» белгілерінің пайда болуы, эякулят мөлшерінің және ондағы сперматозоидтар концентрациясының үдемелі азаюы, соған сәйкес «ерлер» бедеулігінің жиілігінің жоғарылауы мүмкін осымен байланысты деп түсіндірі-леді [11-13].

ГТК әйелдің репродуктивті жүйесіне әсеріне қатысты айтсақ, зиянды факторлардың әйел ағзасына арнайылық әсері басымырақполиморфтылыққатән екендігін атап өткен жөн. Бұл қалыптасу механизмі әртүрлілігімен және репродуктивті функцияның іске асырылуымен, ең алдымен репродуктивті үдерістің қатаң циклдылығымен және оның гипоталамус-гипофиз-аналық бездері жүйесінің барлық звенолар жағдайының тәуелділігімен байланысты [15-16].

Зерттеудің мақсаты-хлорорганикалық пестицидтер кеңінен қолданылған мақта өсіретін аймақта тұратын жасөспірім қыздардың эндокринді жағдайының ерекшеліктерін зерттеу.

\section{Материалдар мен әдістер}

Бағдарламаға сай, зерттеудің 10-17 жас аралығындағы 172 жасөспірім қыздарға (89 негізгі топтағы және 83 салыстырмалы) зерттеу жүргізілді. Тұрғылықты жеріне байланысты олар 2 топқа бөлінді. Бірінші (негізгі) топқа, 1996 - 2003 жылдар аралығындағы кезеңде туылған Қазақстанда Стокгольм конвенциясын бекітпегенге және оларды қолдануға тиым салынған 2008 жылға дейін мақтаны өсіруде хлорорганикалық пестицидтерді кеңінен қолданған Сары-Ағаш ауданының аумағында тұратын 89 қыздар кірді. Зерттеу 2013-2014 жылдары жүргізілді.

Екінші топқа (салыстырмалы) ауыл шаруашылығында мал шаруашылығымен айналысатын Сайрам ауданының аумағында тұратын 83 қыз кірді. Аталған аумақта ешқашан мақта егісі болмаған және хлорорганикалық пестицидтер қолданылмаған. Барлық зерттелген қыздар ауылдық жерлерде өмір сүрген, яғни әлеуметтік-тұрмыстық және климатогеографиялық факторлар бойынша салыстырмалы. Зерттелген қыздар жас бойынша бөлінді.

Гонадотропты гормондардың: фолликулостимулдаушы (ФСГ), лютеиндеуші (ЛГ), пролактин (ПЛ); және стероидты гормондар: «DSL-10-3700 ACTIVE» (USA), "HPLBIOSERV - ELISA" (Germany) реактивтерін қолдана отырып радиоимуннологиялық әдіспен негізгі топтағы 89 қызда және салыстырмалы топтағы 83 қызда эстрадиол (Е2), кортизол (К), дегидроэпиандростерон (ДГЭА) зерттеулері жүргізілді. Гормоналды зерттеу таңғы сағат 10-ға дейін ашқарынға етеккір циклының 3-7 күндері жүргізілді, ал етеккірі болмаған қыздарда кез-келген күні жасалынды.

Алынған мәліметтердің статистикалық өңдеуі «Биостат» талдау бағдарламасы стандартты пакеті көмегімен параметрлік статистика әдістерін қолданыла отырылып 
жүргізілді. Дескрептивті статистика әдістері өзіне орташа арифметикалық бағалау (М) және орташа мәнді қатені (m) кіргізеді. Екі орташа шама көрсеткіштерінің арасындағы нақтылығы Стьюдент критерийі (t) бойынша анықталды. Коэффициент мәнінің деңгейі 0,05 тең немесе одан төмен болғанда статистикалық анық деп саналды.

Зерттелген параметрлер арасындағы байланыс Пирсон корреляциясы коэффициенті көмегімен анықталды. Тікелей корреляциялық байланыс шамасы: 0,3 - әлсіз; 0,3-тен 0,7-дейін - орташа; 0,7-ден 1,0-дейін - тығыз деп саналды [16].

\section{Нәтижесі}

Алдын-ала тексеру және анамнез жинау барысында бізбен пестицидтер әсер ететін аумақта туылған және тұратын қыздарда құрбыларымен салыстырғанда соматикалық және гениталді патология аурушаңдығының жоғарылығы (1,31 және 1,28 есе жиі сәйкес) тұрақталды. Жағымсыз ауданда тұратын қыздарда етеккір циклы бұзылысы құрылымында гипоменструальді синдром және аменореяның басым болуы нейроэндокринді жүейде жүріп жатқан процесстің ауырлығын дәлелдейді. Сонымен қатар, оларда тыныс алу жолдарының және асқазан-ішек трактісінің аурулары анық жиі кездесті ( $<00,001$ және $\mathrm{p}<0,01$ сәйкес), бұл болашақта олардың репродуктивті фнукциясында да міндетті түрде көрініс береді.

Зерттеудің екінші міндетін орындау үшін бізбен қыздарды антропометрия-лық зерттеу және Л. ТаннерТумилович әдістемесі бойынша екіншілік жыныстық жетілу белгілерін бағалау жүргізілді. Алынған нәтижелер, мақта егетін аумақта тұратын қыздарда репродуктивті жүйенің қалыптасуы физикалық және жыныстық жетілу жағынан артта қалып отырғандығын айғақтайды. Бұның бір көрсеткіші болып дене салмағының жетіспеушілігі, сонымен қатар, менархенің орта жасына 12,8土0,2 жас сәйкес келуі, осы анторопометриялық көрсеткішке пубертатты өсудің тым кеш жасқа жылжуы көрініс болып табылады. Басқада негізгі антропометриялық параметрлер артта қалу аясында (тұрған және отырған күйдегі дененің ұзындығы, көкірек клеткасының шеңбері) негізгі топтағы қыздарда пубертатты кезеңнің аяғына таман жәйпақ жамбастың қалыптасуын қадағалау бет алған. Бұл осы адам құрамындағы қыздарда аналық бездері функциясының жеткіліксізділігінің көрсеткіші болуы мүмкін.

Хлорорганикалық пестицидтердің жағымсыз әсеріне душар болған қыздарда 17 жасқа жыныстық жетілу балл тым төмен болған (8,92 балл $\pm 0,4$ балл қарсы $10,33 \pm 0,3$ балл салыстырмалы топта) жыныстық жетілу үдерісінің осы жасқа аяқталмағанын айғақтайды. Бұл зерттелген қыздардың ішкі жыныс мүшелерін ультрадыбыстық зерттеу нәтижелерінде, жатыр мен аналық бездерінің қарқынды өсуіне қарамастан, 17 жас шамасында осы мүшелердің өлшемдері қалыпты көлемге сәйкес келмейтіндігін көрсетті. Сонымен қатар, пестицидтер әсер ететін аумақта тұратын қыздарда құрбыларымен салыстыр-ғанда барлық жас шамасында екі аналық бездерінің де өлшемдерінің анық кіші болғандығы ( $<0,001)$ анықталды.

Кейбір зерттеушілер [17, 18] жануарларға жасаған экспериментальді зерттеулерге негізделіп, пестицидтердің репродуктивті денсаулыққа жағымсыз әсерін «эндокринді зақымдану» гипотезасымен байланыстыратындығын атап өткен жөн. Олар токсиканттар сигналдың эндокринді жүйеге берілуіне әсерін тигізуі мүмкін, бұл әсер ету әсіресе құрсақтық кезең және балалық шақтың анық фазаларында айрықша жүреді деп санайды. Зерттеушілер [19] соңғысын гормонтәрізді ксенобиотиктерге жатқыза отырып, пестицидтердің әсерін эстрогентәрізді әсер етеді деп түсіндіреді. Олар пестицидтер әсер етуіне душар болған қыздарда ерте жыныстық жетілу және ерте менархенің болуын осылай түсіндіреді. Біздің алған мәліметтеріміз мақта егетін ауданда тұратын қыздар физикалық және жыныстық жетілу жағынан артта қалуы анықталып ерекшеленеді.

Біздің зерттеулеріміздің нәтижесі басқада зерттеушілердің мәліметтерімен сәйкес келеді [20]. Сонымен, тұрақты органикалық ластаушылардың, сонымен қатар органикалық пестицидтердің әсерін зерттеу мақсатында пубертатты басталуында ғалымдармен 6-8 жастағы 645 қыздарға тексеру жүргізілді. Пубертаттың кеш басталу жас шамасы қандағы пестицидтер мөлшерінің жоғары болуымен корреляцияланды, осылайша зерттелген қыздарда жыныстық жетілудің кідіруі анықталды.

Осы екі арада, басқа зерттеушілер пестицидтер мен пубертатты кезеңнің басталуы арасындағы байланысты таппады [21]. Зерттеушілердің жыныстық жетілу кезеңінің ерекшелігі туралы мәліметтерінің қайшылылығы, зерттелгендердің әртүрлі іріктелуі, олардың тұратын жерінің жағдайы, патогендік фактордың әсер ету ұзақтығы және тағыда басқаларға байланысты.

Осыған ұқсас Оңтүстік Африкада 9,5 - 13,3 жас шамасындағы ер балаларда жасалынған антропометриялық көрсеткіштеріне пестицидтердің әсерінің зерттеулер нәтижелері қызығушылық туғызады. Пестицидтер әсер ететін аумақта тұратын балаларда бой мен дене салмағының төменгі көрсеткіші, және де бұл айырмашылықтардың 11 жастан төмен жаста айқын болғандығын көрсетті [22].

\section{Талқылау}

Әдеби шолуда бізбен белгіленіп кеткендей кейбір зерттеушілердің ойларынша [23], әртүрлі табиғатты стрессорлар, соның ішінде «химиялық күйзеліс» нейроэндокринді әрекетсізідігінің дамуымен жүретін: гонадотропиндер өндірілуінің күшеюі, эстроген өндірілуінің өсуі, бүйрекүсті бездері мен қалқанша бездерінің гиперфункциясы («экологиялық-генеративті диссонанс») эндокринді қалпына келудегі гипоталамдықгипофизарлы бөлігінің шектен тыс қозуына алып келеді. Дамыған эндокринді жылжулар гипоталамус қозуын тежеуге бағытталған. Мақта өнідірісіндегі жұмысшыларға жүргізілген зерттеулер нәтижелері инсектицидтерді шашумен, сонымен қатар мақта жинаумен $(p<0,01)$ айналысатын жұмысшыларда FSH, LH, және тестостерон деңгейлері анағұрлым жоғары болғандығы осы теорияның дәлелі болып табылады [24].

Шеткерілік қанда гормондарды зерттеу нәтижесі салыстырмалы топтардағы қыздарда жыныстық жетілу кезеңі бойынша гонадотропиндер деңгейі динамикалық жоғарылап, 15-17 жас шамаларында ересек әйелдің деңгейіне жақындағанын көрсетті (кесте 1). Гонадотропиндер деңгейінің жоғарылауы «жетілген тип» үдерісінің құрылуымен репродуктивті жүйенің жұмыс істеуін және овуляторлы циклге өтуін айғақтайды. ЛГ өсу темпі ФСГ-нің осыған ұқсас параметрлерінен артады. 

$(\mathrm{mU} / \mathrm{l})$

\begin{tabular}{|c|c|c|c|c|c|c|}
\hline \multirow[t]{2}{*}{ Гормон-дар } & \multicolumn{3}{|c|}{ Негізгі (n=89) } & \multicolumn{3}{|c|}{ Салыстырмалы (n=83) } \\
\hline & $\begin{array}{l}10-12 \\
(n=28)\end{array}$ & $\begin{array}{l}13-14 \\
(n=31)\end{array}$ & $\begin{array}{l}15-17 \\
(n=30)\end{array}$ & $\begin{array}{l}10-12 \\
(n=23)\end{array}$ & $\begin{array}{l}13-14 \\
(n=30)\end{array}$ & $\begin{array}{l}15-17 \\
(n=30)\end{array}$ \\
\hline ФСГ & $\begin{array}{l}8,11 \pm 0,42 \\
* *\end{array}$ & $\begin{array}{l}10,81 \pm 0,28 \\
* * * *\end{array}$ & $\begin{array}{l}10,79 \pm 0,98 \\
* * * *\end{array}$ & $10,8 \pm 0,96$ & $15,27 \pm 1,21$ & $16,26 \pm 0,21$ \\
\hline ЛГ & \begin{tabular}{|l}
$1,23 \pm 0,13$ \\
$* * * *$
\end{tabular} & $\begin{array}{l}9,66 \pm 0,33 \\
* *\end{array}$ & $\begin{array}{l}10,95 \pm 0,66 \\
* * * *\end{array}$ & $3,56 \pm 0,37$ & $16,30 \pm 2,60$ & $18,42 \pm 1,28$ \\
\hline ЛГ/ФСГ қатынасы & $0,15 \pm 0,03$ & $0,89 \pm 0,07$ & $1,01 \pm 0,13$ & $0,33 \pm 0,07$ & $1,07 \pm 0,21$ & $1,13 \pm 0,16$ \\
\hline
\end{tabular}

Сонымен, негізгі топтағы қыздарда ФСГ және ЛГ деңгейі құрбыларымен салыстырғанда жыныстық жетілу кезеңі бойынша анық төмен болғандығын атап өткен жөн $(\mathrm{p}<0,02)$. Бізбен анықталғандай, пестицидтер әсер ететін аумақта тұратын қыздарда ФСГ және ЛГ салыстырмалы аз өндірілуі, оларда аналық бездерінің гипофункциясының дамуына әкелуі мүмкін.

Пубертатта функционалды гиперандрогениямен байланысты патологиялық симптомдардың дамуында ЛГ және ФСГ-ның абсолютті мөлшері ғана емес, сонымен қатар жоғары қалыптастырушы орталықтардың фукционалды қатына-сыныңда әсер ететіндігі айтарлықтай маңызды. Бізбен жүргізілген зерттеулер екі топтада ЛГ және ФСГ арақатынасы жыныстық жетілу кезеңі бойынша жоғарылайтындығын, осыған қарамастан осы көрсеткіш салыстырмалы топта біркелкі жоғары, негізгі топқа қарағанда барлық жас кезеңдерінде ересек әйелдің қалыпты шегіне жақынырақ $(1,5: 1)$ екендігін көрсетті.

Негізгі топтағы қыздарда қандағы пролактин деңгейі пубертатты кезең бойынша аздап жоғарылады, бірақ құрбыларына қарағанда 10-12 және 13-14 жас шамаларында анық төмен болды $(\mathrm{p}<0,01$ және $\mathrm{p}<0,001$ сәйкес $)$.

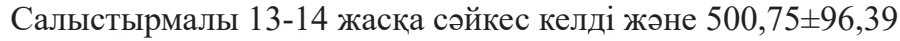

$\mathrm{mU} / 1$ құрады.

Пролактин сүт бездерінің жетілуі және олардағы бөлікшелері мен түтіктердің көбеюінде маңызды орын алатындығы мәлім [25]. Сондықтан оның өндірілуінің аз болуы сүт бездерінің дамуының тежелу үдерісіне әрекет етуі мүмікн. Аналық бездерінде пролактинге байланысты фолликулалар жетілу үдерісінің синхронизациясы және овуляция жүреді, ал жатырда осы гормон прогестерон және эстрогенге рецепторлар санын көбейтеді.

Бұдан басқа, пролактин иммунологиялық үдерістерге де қатысады - гипофизден басқа пролактин лейкоциттермен және лимфоциттермен өндіріледі, және де иммунитеттің белсенуінде қабыну, инфекцияда бұл жасушалармен оның секрециясы жоғарылайды, ал иммуносупрессия кезінде төмендейді. Иммунды үдерістерге қатысатын көптеген жасушалардың беткейлерінде пролактинге рецепторлар бар, және пролактин оған иммунобелсендіруші әсер етеді.

Стероидты гормондар деңгейін зерттеу, аналық бездерінің фукционалды белсенділігімен тікелей байланысты эстрадиол деңгейі барлық жас шамала-рында негізгі топта құрбыларымен салыстырғанда анық төмен болғандығын көрсетті $(\mathrm{p}<0,001)($ кесте 2$)$.

Кесте 2 Салыстырмалы топтардағы қыздарда шеткерілік қандағы стероидты гормондар мөлшері

\begin{tabular}{|c|c|c|c|c|c|c|}
\hline \multirow[t]{2}{*}{ Гормон-дар } & \multicolumn{3}{|c|}{ Негізгі (n=89) } & \multicolumn{3}{|c|}{ Салыстырмалы (n=83) } \\
\hline & $\begin{array}{l}10-12 \\
(\mathrm{n}=28)\end{array}$ & $\begin{array}{l}13-14 \\
(\mathrm{n}=31)\end{array}$ & \begin{tabular}{|l}
$15-17$ \\
$(\mathrm{n}=30)$
\end{tabular} & $\begin{array}{l}10-12 \\
(\mathrm{n}=23)\end{array}$ & \begin{tabular}{|l|}
$3-14$ \\
$(\mathrm{n}=30)$
\end{tabular} & $\begin{array}{l}15-17 \\
(\mathrm{n}=30)\end{array}$ \\
\hline $\mathrm{E} 2(\mathrm{pmol} / \mathrm{l})$ & $\begin{array}{l}78,81 \pm 3,39 \\
* * * *\end{array}$ & $\begin{array}{l}\begin{array}{l}172,85 \pm 1,02 \\
* * * *\end{array} \\
\end{array}$ & $\begin{array}{l}190,0 \pm 11,26 \\
* * * *\end{array}$ & $318,66 \pm 15,61$ & $498,5 \pm 62,13$ & $395,84 \pm 35,80$ \\
\hline К (нмоль/л) & $356,0 \pm 19,5$ & $366,47 \pm 45,5$ & $347,13 \pm 35,3$ & $354,33 \pm 31,7$ & $370,5 \pm 33,99$ & $310,38 \pm 26,6$ \\
\hline ДГЭА (мкг/мл) & $1,32 \pm 0,23$ & $1,60 \pm 0,30$ & $1,98 \pm 0,36$ & $1,46 \pm 0,26$ & $1,65 \pm 0,3$ & $2,13 \pm 0,33$ \\
\hline \multicolumn{7}{|c|}{ Ескерту - айырмашылық салыстырмалы топқа берілген } \\
\hline \multicolumn{7}{|c|}{${ }^{*}$ - $\mathrm{p}<0,05 ;{ }^{* *}$ - $<<0,02 ; *^{* * *}-\mathrm{p}<0,01 ; * * *-\mathrm{p}<0,001$} \\
\hline
\end{tabular}

Негізгі топта эстрадиолдың орташа деңгейі 10-12 жас шамасында ересек әйелдердің осыған ұқсас көрсеткіштерінен қалыптағы-дан төмен шекарада болғандығы, оның осы топтағы қыздарда менархенің кеш болуымен байланысты екендігі көңіл аудартады (12,8 0,2 жас). Бұдан басқа, пестицидтер әсер ететін аумақта тұратын қыздарда эстрогендер көрсеткіштері-нің төмен болуы етеккір циклы бұзылысының құрылымындағы гипоменструалді цикл (33,0\% қарсы 6,25\% салыстырмалы топта) және аменорея (16,7\% қарсы 6,25\% салыстырмалы топта) сияқты нозологиялардың басымырақ болуымен шартталады.

Зерттелген қыздарда, эстрадиол деңгейінің өзгеруі екіншілік жыныстық жетілу белгілерімен тікелей корреляцияланады. Эстроген деңгейінің жоғары-лауымен 10-12 жастан сүт бездерінің ұлғаюы, және ультрадыбыстық зерттеу мәліметі бойынша басымырақ 14 жасқа дейін жатырдың қарқынды өсуі жүреді. Салыстырмалы топтардағы қыздарда дене салмағының өсуі сонымен қатар эстрогендер өндірілуінің жоғарылауында менархе кезеңіне сәйкес келеді.

Дегидроэпиандростерон сульфат (ДГЭА-сульфат) басымырақ бүйрекүсті бездерінің қыртысынан (95\% дейін) және гонадалармен (8-10\%) өндірілетін стероидты гормон болып табылады. Әдеттегідей, оның қандағы жоғарылауы екіншілік жыныстық белгілердің (қолтықасты және қасаға түктенуі, андроген-дердің жанамалық процессі - қолтықасты аймағында тер шығудың жоғары болуы және май бездері функциясының жоғарылауы) ерте жетілуімен жүреді. 
Бізбен жүргізілген зерттеулер, зерттелген қыздарда жас өскен сайын ДГЭАС деңгейі жәйлап жоғарылайды, ол физикалық және жыныстық жетілу үрдістерімен қатар жүретіндігін көрсетті. Бізбен топтар арасында анық айырмашылық анықталған жоқ, әйтседе негізгі топта құрбыларымен салыстыр-ғанда осы гормонның көрсеткіші аздап төмен болды.

Қалыпты жыныстық жетілу үшін кортизол секрециясының оптималды орташа тұрақты деңгейі қажет екендігі мәлім [26, 27]. Зерттеушілер, пубертатты кезеңнің басталуында оның қандағы концентрациясының төмен болуы жыныстық жетілу үдерісніе оның еселеп жұмсалуына байланысты деп санайды.

Бізбен, негізгі топта кортизолдың айтарлықтай ауытқуы анықталған жоқ, бұл осы кезеңде ағзаның бейімділік және қорғаныстық реакциясының жағым-сыз кезі болуы мүмкін.

Осы екі арада, салыстырмалы топта 15-17 жас

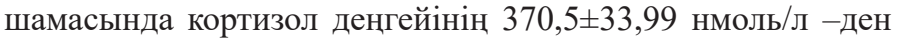
$310,38 \pm 26,6$ дейін төмендеуі байқалды, ол репродуктивті жүйенің жетілуіне оның жұмсалуымен байланысты болуы мүмкін. Салыстырмалы топтарда барлық жас шамасындағы кезеңдерде кортизол деңгейінде анық айырмашылық болмағандығын атап өткен жөн.

Бізбен алынған антропометриялық зерттеулер және екіншілік жыныстық жетілуін бағалау нәтижелері қыздарды гормондарға зерттеу нәтижелерімен сәйкес келеді. Сонымен, зерттеудің үшінші міндетті орындау барысында бізбен негзгі топтағы 89 қыздарда және салыстырмалы топтағы 83 қыздарда гонадотропты (ФСГ, ЛГ, пролактин) және стероидты гормондарды (эстрадиол, кортизол және ДГЭАС) зерттеу жүргізілді.

Жыныстық жетілу кезеңі бойынша негізгі топтағы қыздарда ФСГ және ЛГ деңгейлері құрыбыларымен салыстырғанда анық төмен болғандығы анықталды ( $>0,02)$. Сонымен, негізгі топта 15-17 жас шамасында ФСГ және Лг

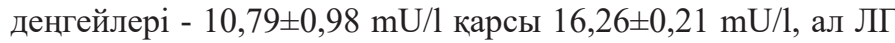

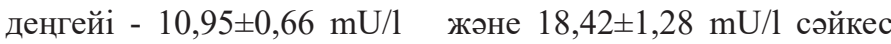
құрады. 10-12 жас және 13-14 жаста пролактинге қатыстыда осыған ұқсас заңдылық тұрақталды. Осы жерде, оларда пролактин және тестостерон деңгейлері төмен болды.

Бізбен алынған зерттеулер нәтижелерінде негізгі топтағы қыздарда гонадотропиндер өндірілуінің төмен болуы эстрогентәрізді әсері бар ағзаға сырттан түскен пестицидтер ұзақ уақыт әсер ете отырып, гипоталамдыгипофизарлы жүйеге алдымен белсендіруші, кейіннен баяулатушы әсер етіп, сонымен қатар өзіндік эстрогендердің жұмысын басқан.

Аналық бездерінің гонадотропты гормондар және стероидты гормондары (эстрогендердің) өндірілуінін төмендеуі мақта егетін аудандарда тұратын қыздарда физикалық және жыныстық жетілуінде көрінісін тапты.

\section{Қорытынды}

Бізбен алынған зерттеулер нәтижелерінде негізгі топтағы қыздарда гонадотропиндер өндірілуінің төмен болуы эстрогентәрізді әсері бар ағзаға сырттан түскен пестицидтер ұзақ уақыт әсер ете отырып, гипоталамдыгипофизарлы жүйеге алдымен белсендіруші, кейіннен баяулатушы әсер етіп, сонымен қатар өзіндік эстрогендердін жұмысын басқан. Аналық бездерінің гонадотропты гормондар және стероидты гормондары (эстрогендердің) өндірілуінің төмендеуі мақта егетін аудандарда тұратын қыздарда физикалық және жыныстық жетілуінде көрінісін тапты [28].

\section{Әдебиет}

1. Mnif W., Hassine AI., Bouaziz A., Bartegi A., Thomas O., Roig B. Effect of endocrine disruptor pesticides. Int J Environ Res Public Health. 2011; 8: 2265-2303.

2. Aripova T.U., Sirota A.R., Batyrbekov A.A. Immunitetiimmunokorektsiyapripestitsidnykhintoksikatsiyakh (Immunity and immunocorrection in pesticidal intoxications) [in Russian]. Tashkent. 2007. 272.

3. Babushkina N.P. Ekologiyagoroda I zdorov'edetei (Ecology of the city and children's health) [in Russian]. M.: MeditsinaZdorov'e; 2005; T.2. 259 p.

4. Belyaev E.N. Stoikieorganicheskiezagryazniteli, soderzhashchiesya v okruzhayushcheisrede, ikhvliyanienazdorov'enaseleniya (Persistent organic pollutants contained in the environment, their impact on human health) [in Russian].EkologicheskiivestnikRossii. 2002;8:10-15.

5. Kul'baevaK.Zh. Ginekologiyadetskogoipodrostkovogo vozrasta (Gynecology of children and adolescence) [in Russian]. Almaty: Evero. 2014. 276 p.

6. Salazar-Garcia F., Gallardo-Diaz E., Ceron-Mireles P. et al. Reproductive effects of occupational DDT exposure among male malaria control workers. Environ. HealthPersp. 2004; 112:542-547.

7. GichevYu.P. Zdorov'echelovekakak indicator ekologiiriskaindustrial'nykhregionov (Human health as an indicator of the ecology of the risk of industrial regions). Vestnik RAMN. 2005; 8: 52-54.

8. Sergeev O.V., Shelepchikov A.A., Denisova T.A. idr. Pilotnoeissledovaniesoderzhaniyastoikikhzagryaznitelei v grudnommolok ezhenshchinChapaevska (Pilot study of persistent contaminants in breast milk of Chapaevsk women) [in Russian]. Vestnik. Ros. VMA. 2008; 3:124-125.

9. Krauthaker B., Reiner E., and Votava-Raii A. et al. Organochlorine pesticides and PCB in human milk collected from mothers nursing hospitalized children. Chemosphere. 2004; 37: 27-32.

10. Sharpe R.H. and Skakkeback N.E. Are estrogens involved in falling sperm counts and disorders of the male reproductive tract? Lancet. 2005; 341: 1392-1395.

11. Nikitin A.I. Gormonopodobnyeksenobiotiki I reproduktivnaya Sistema (Hormon-like xenobiotics And Reproductive System) [in Russian]..Probl. reproduktsii. 2002; 2: 5-15.

12. NikolaevA.A. Vozdeistvietekhnogennykhpollyutantovnaspermatoge-nez(The impact of technogenic pollutants on spermatogonia) [in Russian]. VestnikRos. VMA. 2008; 3:105

13. Khokhlov P.P., Mikhnina E.A., Kalinina N.M. Znachenieimmunofermentnogoopredeleniyaautoantiteldlyadiagnostikizabolevan 
iireproduktivnoifunktsii (The importance of immune-enzyme determination of autoantibodies for the diagnosis of reproductive diseases) [in Russian]. Rossiskiizhurnalimmunologii. 2007; 4: 144-145.

14. GafarovaD.Kh. Sostoyanieimmunnoisistemydevochek-podrostkov s zaderzhkoifizicheskogoipolovogorazvitiya (The state of the immune system of adolescent girls with a delay and physical and sexual development)[in Russian]. Zhurnalteoreticheskoiiklinic heskoimeditsiny.2007; 2 : 49-51.

15. Kozlova I.G. Immunologiyareproduktsii: teoreticheskieiklinicheskieaspekty (Immunology of reproduction: theoretical and clinical aspects)[in Russian]. Sankt-Peterburg: ELBI; 2007. 179 p.

16. Zaitsev V.M., Liflyandskii V.M., Marinkin V.I. Prikladnaya meditsinskaya statistika (Applied Medical Statistics) [in Russian]. Sankt-Peterburg: Foliant.2003; 428 p.

17. Anne Vested, AleksanderGiwercman, Jens Peter Bonde, Gunnar Toft1 Persistent organic pollutants and male reproductive health. Asian Journal of Andrology. 2014; 16: 71-80.

18. Costa E.M., Spritzer P.M., Hohl A., Bachega T.A. Effects of endocrine disruptors in the development of the female reproductive tract. Arq Bras EndocrinolMetabol. 2014; 58(2): 153-61.

19. Michael E. Baker and Gary Hardiman Transcriptional analysis of endocrine disruption using zebrafish and massively parallel sequencing. J MolEndocrinol. 2014; 52(3): 241-256.

20. Windham G.C., Pinney S.M., Voss R.W., Sjodin A., Biro F.M., Greenspan L.C., et all. Brominated Flame Retardants and Other PersistentOrganohalogenated Compounds in Relation to Timing of Puberty in a Longitudinal Study of Girls. Environ Health Perspect. 2015; 14: 171-180.

21. Denham M., Schell L.M., Deane G., Gallo M.V., Ravenscroft J., DeCaprioA.P. Relationship of lead, mercury, mirex, dichlorodi phenyldichloroethylene, hexachlorobenzene, and polychlorinated biphenyls to timing of menarche among Akwesasne Mohawk girls. Pediatrics. 2005;115: 127-134.

22. Ochieng A.A., Dalvie M.A., Little F., Kromhout H. Relationship between environmental exposure to pesticides and anthropometric outcomes of boys in the rural Western Cape, South Africa.S Afr Med J. 2013; 103(12): 942-947.

23. Serov V.N., Kozhin A.A. Ekologo-generativnyidissonansipatofiziologicheskieaspektynarusheniigenerativnoifunktsiitsentral'nog ogenezaAkusherstvoiginekologiya (Ecological-generative dissonance and pathophysiological aspects of disorders of generative function of central genesis Obstetrics and gynecology) [in Russian]. 2005. 12-15.

24. Khan D.A., Ahad K., Ansari W.M., Khan H. Pesticide exposure and endocrine dysfunction in the cotton crop agricultural workers of southern PunjabSee comment in PubMed Commons belowAsia Pac J Public Health.2013; (25-2)181-91.

25. Bernard V., Young J., Chanson P., Binart N. New insights in prolactin: pathological implications Review Nat Rev Endocrinol $2015 ; 265-75$.

26. Fedorov G. N. Gormonal'nyepokazatelipodrostkov 12-16 let (Hormonal indices of adolescents 12-16 years old)[in Russian]. Pediatriya. 2004; (4): 87-90.

27. Sitdikov F. G., Shaikhelislamova M. V., Valeev I. R. i dr. Sootnosheniegormonovkorynadpochechnikov, rostaipolovogor azvitiyashkol'nikov (Ratio of adrenal cortex hormones, growth and sexual development of school children) [in Russian]. Fiziologiyacheloveka. 2004; (30, 3) 140-142.

28. Zhumadilova A.R.Osobennosti stanovleniya reproduktivnoi sistemy devochek-podrostkov v usloviyakh vozdeistviya khlororganicheskikh pestitsidov: avtoref. diss...(Peculiarities of the formation of the reproductive system of adolescent girls under the influence of organochlorine pesticides: author's abstract. diss ...)[in Russian].Turkestan. $2017 ; 21$. 